\title{
Detect it so you can treat it: a case series and proposed checklist to detect neurotoxicity in checkpoint therapy
}

\section{Saskia Bolz}

Universitatsklinikum Essen https://orcid.org/0000-0003-1209-1715

Thivyah Ramakrishnan

Universitatsklinikum Essen

Michael Fleischer

Universitatsklinikum Essen

Elisabeth Livingstone

Universitatsklinikum Essen

\section{Benjamin Stolte}

Universitatsklinikum Essen

Andreas Thimm

Universitatsklinikum Essen

Kathrin Kizina

Universitatsklinikum Essen

Selma Ugurel

Universitatsklinikum Essen

Christoph Kleinschnitz

Universitatsklinikum Essen

Martin Glas

Universitatsklinikum Essen

Lisa Zimmer

Universitatsklinikum Essen

Tim Hagenacker ( $\square$ tim.hagenacker@uk-essen.de )

University Hospital Essen

\section{Research article}

Keywords: melanoma, checkpoint inhibitor, nivolumab, ipilimumab, neurotoxicity, checklist

Posted Date: April 10th, 2020

DOI: https://doi.org/10.21203/rs.3.rs-19760/v1 
License: (c) (i) This work is licensed under a Creative Commons Attribution 4.0 International License. Read Full License

Version of Record: A version of this preprint was published at eNeurologicalSci on March 1st, 2021. See the published version at https://doi.org/10.1016/j.ensci.2021.100324. 


\section{Abstract}

Background: Checkpoint inhibitors show impressive and durable responses in various cancer types and provide new avenues for cancer immunotherapy. However, these drugs have a variety of adverse events. Common autoimmune-related adverse effects include fatigue, hepatitis, skin rash, endocrine deficiencies, and colitis. Neurotoxicity has been reported, but its incidence and course remain unclear.

Methods: To illustrate the broad spectrum of neurotoxicity, we exemplarily report the neurological adverse events of five patients with melanoma and one patient with differentiated thyroid cancer who received checkpoint inhibitors at Essen University Hospital (Essen, Germany).

Results: After treatment with ipilimumab, nivolumab or pembrolizumab, neurotoxic effects included hypophysitis-associated neck pain and headache, Guillain-Barré syndrome, transverse myelitis, acute brachial plexus neuritis, and ocular myasthenia gravis.

Conclusions: Checkpoint inhibitor therapy remains a success story; however, neurological immune-related adverse events may cause severe life-threatening conditions. We propose a checklist for the early detection of neurological adverse events during routine clinical treatment to prevent more severe courses of checkpoint inhibitor-induced neurotoxicity.

\section{Background}

Immune checkpoint inhibitors (ICls) in cancer therapy have significant clinical benefits and result in higher survival rates in patients. Among the approved ICls, drugs targeting anti-cytotoxic T-lymphocyte-associated protein 4 (anti-CTLA-4) and anti-programmed cell death protein 1 (anti-PD-1) are widely implemented in routine clinical treatment.

The ICls suppress inhibitory pathways that block effective anti-tumour T-cell responses. The targeted 'immune checkpoints' control disproportionate excessive immune activation and tumour cells seem to use them as a vehicle to evade the immune system [1]. Ipilimumab was one of the first anti-CTLA-4 ICI to significantly improve disease outcomes in patients with advanced melanoma [2].

Nivolumab and pembrolizumab block the PD-1 receptor and thus suppress negative regulatory pathways in T-cell responses. Programmed cell death protein 1 and its ligand (PD-L1) inhibit T-cell activation and affect cell death by diminishing cell growth factors and survival signals [3]. Genetic polymorphisms in the PD-1 locus in humans increase the risk of various autoimmune diseases [4, 5]. Immune-related adverse events (irAE) in checkpoint therapy may result from impeded self-tolerance from the loss of T-cell inhibition as a predictable side effect [6]. 'Removing the brakes' of the immune systems has resulted in various irAEs. The most frequent are colitis, hepatitis, skin rashes or other dermatological complications, interstitial pneumonitis, and endocrine deficiencies, such as thyroiditis or hypophysitis. In general, irAEs seem to occur at a higher rate with CTLA-4 blockade than with anti-PD-1 therapy and at a greater degree of severity when combining CTLA-4 and PD-1 blockade [7, 8]. Neurological irAEs are less common, with an incidence of $0.9 \%-14 \%[9,10]$, and can result in severe or fatal complications $[11-13,29]$. 
To illustrate the broad spectrum of neurotoxicity after ICI therapy, we present a case series of six cancer patients who experienced neurological irAEs. We also propose a checklist to detect neurologic irAEs as early as possible during routine clinical treatment.

\section{Methods}

Patients treated with ICls at the Departments of Dermatology, Endocrinology, and Neurology at Essen University Hospital (Essen, Germany) from 2015 to 2019 were retrospectively reviewed. Five patients with malignant melanoma and one patient with thyroid cancer were identified with exemplary neurological irAEs. They were continuously monitored and evaluated during and after ICI treatment. Cases \#1 and \#5 were enrolled in ongoing double-blind clinical trials; therefore, the actual ICI used was unknown. Data were extracted by clinical examination protocols and chart review. According to the local regulation (Essen University ethics committee), ethics committee approval was not required to perform retrospective data analysis.

\section{Results}

\section{Case \#1: Excruciating neck pain and headache caused by hypophysitis}

A 40-year-old woman was enrolled in a double-blind clinical trial comparing adjuvant ipilimumab and nivolumab versus nivolumab monotherapy in patients with metastatic melanoma. After 2 months, the patient complained of new and intense neck pain, holocephalic headache and signs of fatigue. The neurological examination was unremarkable. Her medical history was negative for signs of a primary headache disorder. Cervical and cerebral magnetic resonance imaging (MRI) scans showed no significant changes. Laboratory work up revealed autoimmune hypophysitis with adrenal insufficiency. Hormone replacement therapy was immediately initiated, including an intravenous (i.v.) prednisolone bolus (100 $\mathrm{mg}$ ), followed by hydrocortisone substitution (30 mg daily) and slow tapering to $15 \mathrm{mg}$ daily (table 1). The neurological symptoms rapidly and completely resolved. Ten days later, blood analysis revealed thyroid dysfunction. The pituitary dysfunction continued for several months; therefore, chronic hypophysitis was diagnosed. However, neurological symptoms did not recur.

\section{Case \#2: Bilateral facial nerve palsy in a case of Guillain-Barré syndrome}

A 72-year-old man with melanoma was treated within the same adjuvant trial as in Case \#1. Owing to pulmonary and cerebral disease progression, treatment within the trial was stopped. The patient was switched to combination immunotherapy with ipilimumab (3 mg/kg) and nivolumab (1 mg/kg). After the third infusion of combination therapy, he presented with slurred speech and incomplete eye lid closure due to bilateral facial nerve palsy. Five to 6 weeks before symptom onset, he experienced a few days of fever, headache, adynamia and loss of appetite. An examination revealed mild deep tendon reflexes and loss of the Achilles' tendon reflex, positive Romberg's sign and mild dysmetria of the upper extremities.

Electrophysiological studies revealed prolonged F-wave latencies in several nerves, A-waves, reduced nerve conduction velocity and prolonged distal motor latency delay consistent with demyelinating 
polyneuropathy (Figure 1). The cerebrospinal fluid (CSF) had pleocytosis (20 leukocytes/ $\mu \mathrm{L}$ ) and an elevated protein level (98 mg/dL). Inflammation and meningeal carcinomatosis were absent in cranial MRI studies.

For 3 consecutive days, methylprednisolone ( $1 \mathrm{~g}$ i.v.) was administered daily. His symptoms rapidly improved and therapy was continued with intravenous immunoglobulin (IVIG).

\section{Case \#3: Transverse myelitis}

In 2015, a 55-year-old man was diagnosed with malignant melanoma with cervical and pulmonary metastasis. At that time, he was treated with ipilimumab. After the second infusion and 2 months after initiating ICl therapy, the patient complained of sudden loss of sensibility in his hands, gluteal region and legs, primarily on the left side, and weakness of his left hand. Neurological examination showed exaggerated deep tendon reflexes, clonus of the lower extremity and weakness in his left lower and in both upper extremity. He presented hypoesthesia in dermatomes C5-T1 on the left side and dermatomes L3S2 on the right side, and from dermatome L2 downwards along the left side, pallanaesthesia of the lower extremities and ataxia. An MRI image of the spine revealed gadolinium enhancement at the $\mathrm{C} 1$ and $\mathrm{C} 3-5$ spinal cord levels. He was diagnosed with acute transverse myelitis (Figure 2). The CSF showed 8 leukocytes $/ \mu \mathrm{L}$ and an elevated protein level $(72 \mathrm{mg} / \mathrm{dL})$. Extensive microbacterial and virological studies were negative. Tumour cells were also undetectable. Immunosuppressive therapy with methylprednisolone ( $1 \mathrm{~g}$ i.v.) was administered daily for 5 consecutive days. Four days later, symptoms improved. Corticosteroids were tapered during the following 4 weeks. The follow-up examinations revealed residual hypoesthesia and paraesthesia, and slightly reduced strength of the left hand and vivid reflexes. In terms of tumour growth, the patient had a complete response to ipilimumab and remains without a relapse 4 years later.

\section{Cases \#4 and \#5: Brachial plexus neuritis}

Two patients with malignant melanoma were neurologically asymptomatic when nivolumab and ipilimumab, respectively, were administered. The first patient (Case \#4), a 51-year-old woman, developed autoimmune hepatitis, autoimmune colitis and thromboembolic incidents after receiving a combined therapy with nivolumab ( $1 \mathrm{mg} / \mathrm{kg}$ ) and ipilimumab (3 mg/kg). After symptoms resolved, the therapy regimen continued with biweekly nivolumab monotherapy $(3 \mathrm{mg} / \mathrm{kg})$.

After 11 months following the 20th infusion of nivolumab ( $3 \mathrm{mg} / \mathrm{kg})$, she experienced massive pain in the left shoulder and neck area, which spread to the left arm. She presented to the neurology department after developing severe proximal and moderate distal weakness of the extremities. Pain was rated as 8-9 of 10 on a numeric rating scale. The left brachioradialis reflex was reduced. Electrophysiological studies conducted 5 days after symptom onset revealed no signs of chronic nerve damage in keeping with acute idiopathic plexus neuritis. The CSF had mild pleocytosis (5 leukocytes $/ \mu \mathrm{L}$ ) with a normal protein level. Viral and bacterial pathogens and tumour cells were undetectable. Paresis rapidly responded within 3 days of intravenous methylprednisolone ( $1 \mathrm{~g} /$ day $)$. No symptoms recurred with continued ICl therapy. 
The second patient (Case \#5), a 27-year-old woman, received ipilimumab and nivolumab simultaneously or nivolumab as monotherapy in a randomized double-blind clinical trial. Eight months after beginning treatment, she complained of having pain in the left armpit and periaxillary area for more than 1 week when numbness, paraesthesia of the fourth and fifth finger along with mildly reduced strength in flexion and spreading of fingers of the left hand occurred. The left brachioradialis reflex was reduced; therefore, brachial plexus neuritis was diagnosed. The patient refused lumbar puncture and intravenous corticoids. However, the patient responded rapidly to oral steroids ( $100 \mathrm{mg}$ prednisolone for 3 days and tapering over 8 weeks) and showed normal function of the left extremity within several days of treatment.

Both patients continued ICl treatment 3 weeks after the onset of complaints. The neuritis did not recur.

\section{Case \#6: Ocular myasthenia gravis}

A 56-year-old man was diagnosed with thyroid cancer and pulmonary metastases. He was treated with pembrolizumab off-label after tumour progression, after previously undergoing radioiodine treatment, and levatinib and sorafenib therapy. Within 36 hours following the second pembrolizumab infusion and 3.5 weeks after initiating treatment, the patient developed diplopia, which worsened within 1 day. Ten days later, he had right sided ptosis, which caused near-complete eye closure. Over several days, he also developed incomplete ptosis on the left side. Dysarthria, dysphagia, or weakness of the extremities was absent. When he presented to our department, his Quantitative Myasthenia Gravis score was 10 points (of 39 points), which indicated ICl-induced myasthenia gravis (MG). Autoantibodies against neuromuscular junction proteins were negative. Repetitive nerve stimulation of the left facial nerve showed no decrement. His symptoms rapidly improved with prednisone ( $1 \mathrm{mg} / \mathrm{kg} /$ day), followed by slow tapering and symptomatic cholinesterase inhibitor therapy (pyridostigminbromide, $180 \mathrm{mg} /$ day). During the following 6 weeks, no indication of recurrence or generalization of MG occurred. Therefore, pembrolizumab therapy was continued.

Table 1 Patients' characteristics and the clinical findings of neurological irAEs associated with ICI therapy 


\begin{tabular}{|c|c|c|c|c|c|c|}
\hline & Case 1 & Case 2 & Case 3 & Case 4 & Case 5 & Case 6 \\
\hline Age & 40 & 72 & 55 & 51 & 27 & 56 \\
\hline Sex & Female & Male & Male & Female & Female & Male \\
\hline Tumor & $\begin{array}{l}\text { Metastatic } \\
\text { melanoma (MM) }\end{array}$ & $\mathrm{MM}$ & $\mathrm{MM}$ & $\mathrm{MM}$ & $\mathrm{MM}$ & $\begin{array}{l}\text { Differentiated } \\
\text { thyroid cancer }\end{array}$ \\
\hline Checkpoint & Nivolumab & Nivolumab +Ipilimumab vs. & & Ipilimumab + & Nivolumab & \\
\hline Inhibitor & $\begin{array}{l}\text { +Ipilimumab vs. } \\
\text { Nivolumab }\end{array}$ & $\begin{array}{l}\text { Nivolumab, } \\
\text { Ipilimumab }+ \\
\text { Nivolumab }\end{array}$ & Ipilimumab & $\begin{array}{l}\text { Nivolumab, } \\
\text { followed by } \\
\text { Nivolumab } \\
\text { monotherapy }\end{array}$ & $\begin{array}{l}\text { +Ipilimumab } \\
\text { vs. } \\
\text { Nivolumab }\end{array}$ & Pembrolizumab \\
\hline $\begin{array}{l}\text { Time of } \\
\text { initiation to } \\
\text { symptoms }\end{array}$ & 2 months & 1,5 months & 2 months & 11 months & 8 months & 3,5 weeks \\
\hline $\begin{array}{l}\text { Clinical } \\
\text { features }\end{array}$ & $\begin{array}{l}\text { Frontal localized, } \\
\text { pressing } \\
\text { headache, } \\
\text { fatigue }\end{array}$ & $\begin{array}{l}\text { Bilateral facial nerve paralysis, } \\
\text { reduced tendon reflexes, } \\
\text { positive Romberg sign, mild } \\
\text { dysmetria of upper extremities }\end{array}$ & $\begin{array}{l}\text { Hypoesthesia } \\
\text { lower extremities, } \\
\text { paresis, } \\
\text { exaggerated } \\
\text { tendon } \\
\text { reflexes, clonus }\end{array}$ & $\begin{array}{l}\text { Pain and weakness } \\
\text { of left arm, } \\
\text { reduced tendon } \\
\text { reflexes }\end{array}$ & $\begin{array}{l}\text { Periaxillary } \\
\text { pain and } \\
\text { weakness of } \\
\text { left hand, } \\
\text { hypoesthesia } \\
\text { reduced } \\
\text { reflexes }\end{array}$ & $\begin{array}{l}\text { Diplopia, } \\
\text { bilateral ptosis }\end{array}$ \\
\hline Diagnosis & $\begin{array}{l}\text { Neck pain and } \\
\text { headache } \\
\text { attributed to } \\
\text { hypophysitis }\end{array}$ & Guillain-Barré syndrome & $\begin{array}{l}\text { Transverse } \\
\text { Myelitis }\end{array}$ & $\begin{array}{l}\text { Brachial plexus } \\
\text { neuritis }\end{array}$ & $\begin{array}{l}\text { Brachial } \\
\text { plexus } \\
\text { neuritis }\end{array}$ & $\begin{array}{l}\text { Ocular } \\
\text { myasthenia } \\
\text { gravis }\end{array}$ \\
\hline Diagnostics & $\begin{array}{l}\text { Cortisol, ACTH, } \\
\text { TSH, fT3, fT4, } \\
\text { IGF-1, LH, FHS, } \\
\text { estradiol; cranial } \\
\text { MRI }\end{array}$ & $\begin{array}{l}\text { CSF with pleocytosis, protein } \\
\text { level of } 98 \mathrm{mg} / \mathrm{dl} \text {, } \\
\text { demyelinating } \\
\text { polyneuropathy }\end{array}$ & $\begin{array}{l}\text { CSF with mild } \\
\text { pleocytosis, } \\
\text { contrast } \\
\text { enhancement C1 } \\
\text { and C3-5 in spinal } \\
\text { MRI }\end{array}$ & $\begin{array}{l}\text { CSF with mild } \\
\text { pleocytosis }\end{array}$ & denied & $\begin{array}{l}\text { Myasthenia } \\
\text { gravis- } \\
\text { associated } \\
\text { antibodies } \\
\text { negative, } \\
\text { decrement not } \\
\text { detectable }\end{array}$ \\
\hline Treatment & $\begin{array}{l}\text { 100mg } \\
\text { prednisolone i.v. } \\
\text { bolus + } \\
\text { hydrocortisone } \\
\text { substitution }\end{array}$ & $\begin{array}{l}\text { 1g methylprednisolone i.v. for } \\
3 \mathrm{~d}+\text { IVIG }(0,4 \mathrm{~g} / \mathrm{kg} / \mathrm{d} \text { for } 5 \\
\text { d) }\end{array}$ & $\begin{array}{l}1 \mathrm{~g} \\
\text { methylprednisolone } \\
\text { i.v. for } 5 \mathrm{~d}+\text { taper } \\
\text { over } 4 \text { weeks }\end{array}$ & $\begin{array}{l}\lg \\
\text { methylprednisolone } \\
\text { i.v. for 3d }\end{array}$ & $\begin{array}{l}\text { 100mg } \\
\text { prednisolone } \\
\text { p.o. + taper } \\
\text { over } 8 \text { weeks }\end{array}$ & $\begin{array}{l}\text { prednisolone } \\
1 \mathrm{mg} / \mathrm{kg} / \mathrm{d} \text { p.o. } \\
\text { + taper over } 6 \\
\text { weeks + } \\
\text { pyridostigmin }\end{array}$ \\
\hline $\begin{array}{l}\text { Oncological } \\
\text { outcome }\end{array}$ & $\begin{array}{l}\text { Progression of } \\
\text { metastases }\end{array}$ & $\begin{array}{l}\text { Progression of } \\
\text { metastases }\end{array}$ & $\begin{array}{l}\text { Complete } \\
\text { remission }\end{array}$ & $\begin{array}{l}\text { Stable tumor and } \\
\text { pulmonary } \\
\text { metastasis }\end{array}$ & Stable & Stable \\
\hline $\begin{array}{l}\text { Neurological } \\
\text { outcome }\end{array}$ & Complete & $\begin{array}{l}\text { Partially resolved with } \\
\text { sequelae }\end{array}$ & $\begin{array}{l}\text { Excellent, mild } \\
\text { residual } \\
\text { Hypoesthesia, vivid } \\
\text { reflexes }\end{array}$ & Complete & Complete & $\begin{array}{l}\text { Excellent, mild } \\
\text { residual ptosis } \\
\text { on one side }\end{array}$ \\
\hline $\begin{array}{l}\text { Follow-up } \\
\text { period }\end{array}$ & 16 months & 1 month & 4 years & 15 months & 12 months & 5 months \\
\hline
\end{tabular}

\section{Discussion}


these findings, we propose a checklist to detect neurological irAEs as early as possible during routine clinical treatment. Neurological complications potentially related to ICI therapy vary from acute peripheral neuropathy (e.g. acute inflammatory demyelinating polyneuropathy [AIDP] and chronic inflammatory demyelinating polyneuropathy [CIDP]) [14-16] and MG [17-19] to granulomatous inflammation of the CNS [19], multifocal CNS demyelination [20], meningitis [21], myelitis [19] and encephalopathy [10]. In particular, when ICl is implemented by non-neurological professionals, neurotoxicity can be difficult to diagnose and may therefore be underreported.

Hypophysitis is a common irAE with ICl therapy, and its overall incidence is up to 9\% [22]. However, neurological symptoms are often considered secondary. In Case \#1, the leading symptom of neck pain and cephalgia led to a diagnosis of endocrine dysfunction.

Case \#3 illustrates a possible irAE affecting the central nervous system. Transverse myelitis occurred after only two doses of ipilimumab. A similar course of adverse events, which occurred 2 months after initiating ipilimumab therapy, was described in a case of transverse myelitis at spinal cord level T9-10 [16]. When high-dose intravenous steroids were administered, the patient recovered to a certain extent throughout a 2week period and ICl therapy was withheld. Wilson et al. [23] presented a case of longitudinally extensive transverse myelitis after pembrolizumab treatment in which the patient improved after the intravenous administration of corticosteroids, immunoglobulins and plasma exchange. Common autoantibody profiles associated with extensive transverse myelitis, such as aquaporin- 4 and myelinoligodendrocyte glycoprotein antibodies, were not detected. As in our case, the patient had an excellent neurological outcome during the follow up.

The peripheral nervous system may be particularly vulnerable to immune-mediated toxicity when impaired T-cell reactions occur [24], which is represented by the manifestation of many cases during ICl therapy. Case \#2 had a dire irAE because of its potentially fatal course. Similar cases have been reported when ipilimumab, nivolumab, the combination of both, or pembrolizumab was administered. Some of these cases had rapidly ascending symptoms and some cases had a fatal outcome because of multiorgan failure or respiratory insufficiency $[14,21,25-26]$. Clinicians should consider that, because checkpoint therapies cause irAEs, corticosteroids are a first-line treatment option in treating ICl-induced Guillain-Barré syndrome.

As in Cases \#4 and \#5, brachial plexus neuritis after PD-1 antibody treatment was reported in one patient after nine infusions of pembrolizumab, and in another patient after nine infusions of nivolumab both with a rebound of symptoms when weaned from corticosteroids and with a rapid response to corticosteroids and a full regaining of function [27]. Compared to idiopathic pathogenesis, ICl-induced plexus neuropathies develop with an acute onset and seem to predominantly affect the lower trunk and muscle atrophy is absent; pain and motor and sensory symptoms respond immediately to high-dose corticosteroids [27].

Generalized and ocular myasthenic syndromes have been reported with ICI treatment [28]. Fifty-nine percent of patients who developed MG after ICI therapy were positive for antibodies against the 
neuromuscular junction [29]. Myasthenia gravis can spontaneously develop in CTLA-4 knockout mice [30]. The overexpression of PD-1 potentiates CD 8 + T-cell exhaustion; therefore, anti-PD-1 ICl may stimulate the exacerbation of symptoms in patients with pre-existing MG [31]. Myasthenia gravis is a severe condition with an ICl-induced MG-related mortality rate of approximately 30\% [29].

The potential severity of neurological irAEs stresses the importance of an attentive screening and examination when treating patients with ICls. Therefore, we suggest a checklist-especially for nonneurologists-to detect neurological irAEs as early as possible during clinical routine treatment (Table 2).

Given that our findings and checklist are based entirely on cases series and review of the literature without available prospective data, our results were limited and future prospective studies are needed for validation in the real world.

\section{Conclusions}

All patients in this case series had a significant response to corticosteroid treatment. Despite the severity of some neurologic toxic effects, they are generally treatable and manageable if detected early and treated swiftly with corticosteroids and other immunosuppressive agents, as necessary. Treatment was discontinued in the patients with transverse myelitis and Guillain-Barré syndrome. By contrast, for the patients with brachial plexus neuritis and $M G$, the $\mathrm{ICl}$ therapy was continued. Our case series underlines the importance of vigilant and multidisciplinary management of neurological complications with ICI therapy. We suggest a checklist to screen for neurological irAE in daily clinical practice and by nonneurologists, and for the implementation of prompt immunosuppressive treatment.

\section{Abbreviations}

AIDP acute inflammatory demyelinating polyneuropathy

anti-CTLA-4 anti-cytotoxic T-lymphocyte-associated protein 4

anti-PD-1 anti-programmed cell death protein 1

CIDP chronic inflammatory demyelinating polyneuropathy

CNS central nervous system

CSF cerebrospinal fluid

$\mathrm{ICl} \quad$ immune checkpoint inhibitor

irAE immune-related adverse events

i.v. intravenous

IVIG intravenous immunoglobulin 
MG Myasthenia Gravis

MRI magnetic resonance imaging

PD-L1 programmed cell death protein 1 ligand

\section{Declarations}

Ethical approval and consent to participate: According to the local regulation (Essen University ethics committee), ethics committee approval was not required to perform retrospective data analysis. All persons gave their informed written consent prior to their inclusion in the study.

Consent for publication: All patients gave their informed consent for publication of their anonymized data.

Availability of data and materials: The datasets used and analysed during the current study are available from the corresponding author on reasonable request.

Competing interests: SB received travel support from Octapharma (Lachen, Schweiz). EL served as consultant and/or received honoraria from Amgen (Thousand Oaks, CA, USA), Actelion (Allschwil, Switzerland), Roche (Basel, Switzerland), Bristol-Myers Squibb (New York, NY, USA), Merck Sharp \& Dohme (Kenilworth, NJ, USA), Novartis (Basel, Switzerland), Janssen (Beerse, Belgium), Medac (Wedel, Germany), and travel support from Amgen, Merck Sharp \& Dohme, Bristol-Myers Squibb, Medac, Pierre Fabre (Paris, France), Sunpharma (Mumbai, India) and Novartis. SU declares research support from Bristol-Myers Squibb and Merck Serono (Geneva, Switzerland); speakers and advisory board honoraria from BristolMyers Squibb, Merck Sharp \& Dohme, Merck Serono, Novartis and Roche, and travel support from BristolMyers Squibb, Merck Sharp and Dohme. LZ served as consultant or/and received honoraria from Roche, Bristol-Myers Squibb, Merck Sharp \& Dohme, Novartis, Sanofi (Paris, France), and Pierre Fabre, and travel support from Amgen, Merck Sharp \& Dohme, Bristol-Myers Squibb, Novartis, Pierre Fabre, and Sanofi. Tim Hagenacker received travel compensation, advisory board and lecture honoraria from CSL Behring (King of Prussia, PA, USA), Biogen and Alexion and is and editorial board member (associate editor) of BMC Neurology. TR, MF, BS, AT, KK, MG and CK have no conflicts of interest.

Funding: None.

Author contributions: All authors contributed to the study conception and design. Material preparation, data collection and analysis were performed by SB, TR and MF. Data collection and investigation was also performed by BS, AT and KK. The first draft of the manuscript was written by SB and TH. LZ, SU and EL reviewed and edited the manuscript. MG and CK supervised and aided in interpreting he results. All authors commented on previous versions of the manuscript. Also, all authors read and approved the final manuscript.

Acknowledgments: None. 


\section{References}

1. Mahoney KM, Freeman GJ, McDermott DF. The next immune-checkpoint Inhibitors: PD-1/PD-L1 blockade in Melanoma. Clin Ther. 2015;37:764-82.

2. Schadendorf D, Hodi FS, Robert C, Weber JS, Margolin K, Hamid O, et al. Pooled analysis of long-term survival data from phase II and phase III trials of ipilimumab in unresectable or metastatic melanoma. J Clin Oncol. 2015;33:1889-94.

3. Freeman GJ, Long AJ, Iwai Y, Bourque K, Chernova T, Nishimura $\mathrm{H}$, et al. Engagement of the PD-1 immunoinhibitory receptor by a novel $B 7$ family member leads to negative regulation of lymphocyte activation. J Exp Med. 2000;192:1027-34.

4. Nielsen C, Hansen D, Husby S, Jacobsen BB, Lillevang ST. Association of a putative regulatory polymorphism in the PD-1 gene with susceptibility to type 1 diabetes. Tissue Antigens. 2003;62:4927.

5. Velazquez-Cruz R, Orozco L, Espinosa-Rosales F, et al. Association of PDCD1 polymorphisms with childhood-onset systemic lupus erythematosus. Eur J Hum Genet. 2007;15:336-41.

6. Horio Y. Management of toxicities of Immune checkpoint Inhibitors. Gan To Kagaku Ryoho. 2017;44:185-90. In Japanese.

7. Larkin L, Chiarion-Sileni J, Gonzalez V. R, et al. Combined nivolumab and ipilimumab or monotherapy in untreated melanoma. New Engl J Med. 2015;373:23-34.

8. Wolchok JD, Chiarion-Sileni V, Gonzalez R, Rutkowski P, Grob JJ, Cowey CL, et al. Overall Survival with Combined Nivolumab and Ipilimumab in Advanced Melanoma. New Engl J Med. 2017;377:1345-56.

9. Spain L, Walls G, Julve M, O'Meara K, Schmid T, Kalaitzaki E, et al. Neurotoxicity from immunecheckpoint inhibition in the treatment of melanoma: a single centre experience and review of the literature. Ann Oncol. 2017;28:377-85.

10. Larkin J, Chmielowski B, Lao CD, Hodi FS, Sharfman W, Weber J, et al. Neurologic serious adverse events associated with nivolumab plus ipilimumab or nivolumab alone in advanced melanoma, including a case series of encephalitis. Oncologist. 2017;22:709-18.

11. Spain L, Diem S, Larkin J. Management of toxicities of immune checkpoint inhibitors. Cancer Treat Rev. 2016;44:51-60.

12. Touat M, Talmasov D, Ricard D, Psimaras D. Neurological toxicities associated with immunecheckpoint inhibitors. Curr Opin Neurol. 2017;30:659-68.

13. Wang DY, Salem JE, Cohen JV, Chandra S, Menzer C, Ye F, et al. Fatal toxic effects associated with immune checkpoint inhibitors: a systematic review and meta-analysis. JAMA Oncol. 2018;4:1721-8.

14. Wilgenhof S, Neyns B. Anti-CTLA-4 antibody-induced Guillain-Barre syndrome in a melanoma patient. Ann Oncol. 2011;22:991-3.

15. Schneiderbauer R, Schneiderbauer M, Wick W, Enk AH, Haenssle HA, Hassel JC. PD-1 Antibodyinduced Guillain-Barre Syndrome in a patient with metastatic melanoma. Acta Derm-Venereol. 2017;97:395-6. 
16. Liao B, Shroff S, Kamiya-Matsuoka C, Tummala S. Atypical neurological complications of ipilimumab therapy in patients with metastatic melanoma. Neuro-Oncolology. 2014;16:589-93.

17. Montes V, Sousa S, Pita F, Guerreiro R, Carmona C. Myasthenia gravis induced by ipilimumab in a patient with metastatic melanoma. Front Neurol. 2018;9:150.

18. Loochtan Al, Nickolich MS, Hobson-Webb LD. Myasthenia gravis associated with ipilimumab and nivolumab in the treatment of small cell lung cancer. Muscle Nerve. 2015;52:307-8.

19. Voskens CJ, Goldinger SM, Loquai C, Robert C, Kaehler KC, Berking C, et al. The price of tumor control: an analysis of rare side effects of anti-CTLA-4 therapy in metastatic melanoma from the ipilimumab network. PLoS One. 2013;8:e53745.

20. Maurice C, Schneider R, Kiehl TR, Bavi P, Roehrl MH, Mason WP, et al. Subacute CNS Demyelination after Treatment with nivolumab for melanoma. Cancer Immunol Res. 2015;3:1299-302.

21. Bot I, Blank CU, Boogerd W, Brandsma D. Neurological immune-related adverse events of ipilimumab. Practical Neurology. 2013;13:278-80.

22. Joshi MN, Whitelaw BC, Palomar MT, Wu Y, Carroll PV. Immune checkpoint inhibitor-related hypophysitis and endocrine dysfunction: clinical review. Clin Endocrinol. 2016;85:331-9.

23. Wilson R, Menassa DA, Davies AJ, Michael S, Hester J, Kuker W, et al. Seronegative antibody-mediated neurology after immune checkpoint inhibitors. Ann Clin Transl Neur. 2018;5:640-5.

24. Klein CJ. Autoimmune-mediated peripheral neuropathies and autoimmune pain. H In: Handbook of Clinical Neurology vol. 133. Amsterdam: Elsevier, 2016;pp. 417-46.

25. Gaudy-Marqueste C, Monestier S, Franques J, Cantais E, Richard MA, Grob JJ. A severe case of ipilimumab-induced Guillain-Barre syndrome revealed by an occlusive enteric neuropathy: a differential diagnosis for ipilimumab-induced colitis. J Immunother. 2013;36:77-8.

26. Manam R, Martin JL, Gross JA, Chaudhary D, Chowdhary S, Espinosa PS, et al. Case Reports of Pembrolizumab-induced acute inflammatory demyelinating polyneuropathy. Cureus. 2018;10:e3371.

27. Alhammad RM, Dronca RS, Kottschade LA, Turner HJ, Staff NP, Mauermann ML, et al. plexus neuritis associated with anti-programmed cell death-1 antibodies: report of 2 cases. Mayo Clinic Proceedings: Innovations, Quality \& Outcomes 2017;1:192-197.

28. Garcia CR, Cox JN, Villano JL. Myasthenia gravis and Guillain-Barré syndrome adverse events with immune checkpoint inhibitors. J Clin Oncol. 2018;36:37-7.

29. Makarious D, Horwood K, Coward JIG. Myasthenia gravis: an emerging toxicity of immune checkpoint inhibitors. Eur J Cancer. 2017;82:128-36.

30. Waterhouse P, Penninger JM, Timms E, Wakeham A, Shahinian A, Lee KP, et al. Lymphoproliferative disorders with early lethality in mice deficient in Ctla-4. Science. 1995;270:985-8.

31. Calabrese L, Velcheti V. Checkpoint immunotherapy: good for cancer therapy, bad for rheumatic diseases. Ann Rheum Dis. 2017;76:1-3.

\section{Figures}




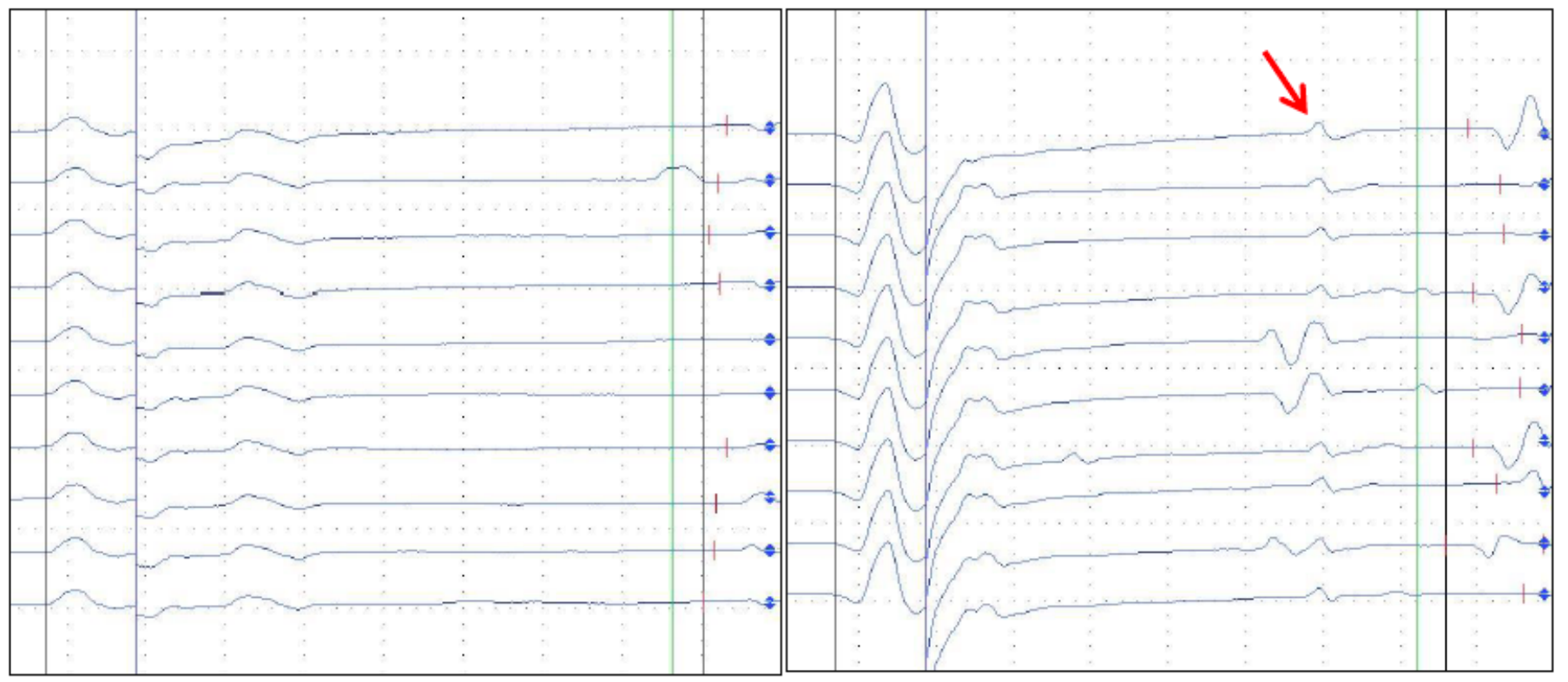

Figure 1

Electroneurography of several nerves show F-wave latencies and A-waves in the left peroneal nerve (left) and tibial nerve (right)
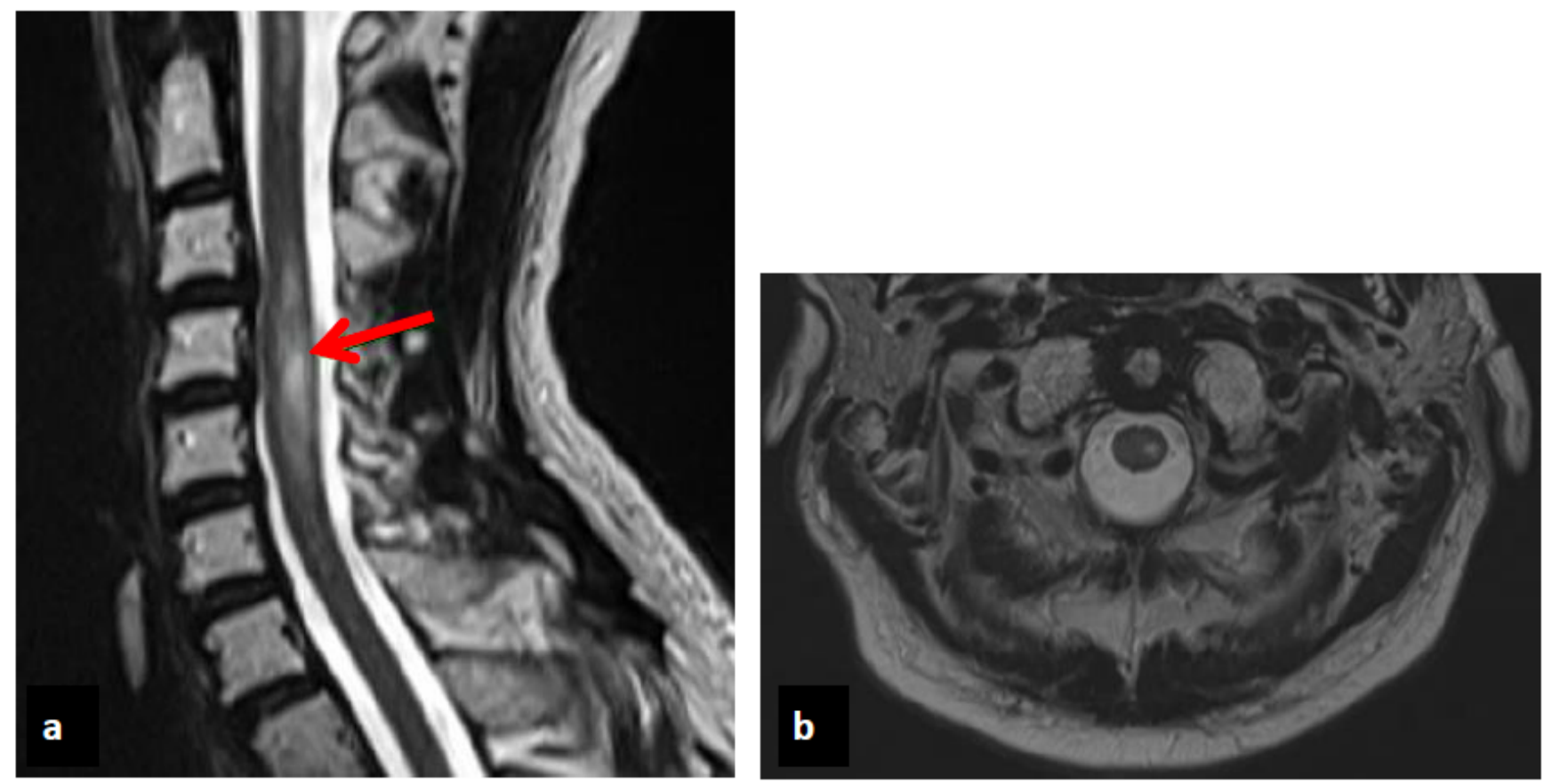
Figure 2

Axial (a) and sagittal (b) contrast magnetic resonance image findings of C1 and C3-5 using the T-2 weighted sequence

\section{Checklist for important questions to potentially detect neurological irAE:}

Gait disturbance, reduced tendon reflexes, dysesthesia, hypoesthesia (peripheral neuropathy) ?

Gait disturbance, limb weakness, cranial nerve involvement, respiratory dysfunction (AIDP)?

Impaired speech, incomplete closing of mouth or eyes, conjunctivitis (cranial nerve palsy/ AIDP)?

Severe constipation (inflammatory enteric neuropathy)?

Pain in shoulder, arm or hand, muscle weakness, hypoesthesia (brachial plexus neuritis)?

$\square$ Lower back pain, proximal weakness, dysesthesia (lumbosacral plexus neuritis) ?

Gait disturbance, limb muscle weakness, bladder and bowel disorder (CNS demyelination)?

Headache, especially frontal, unusual fatigue, impaired vision (hypophysitis)?

Bilateral impaired vision (bilateral optic neuritis) ?

Adynamia, fever, headache, neck stiffness (aseptic meningitis) ?

Fever, confusion, dizziness (meningitis, encephalitis)?

Muscle pain and weakness, creatin kinase elevation (myositis)?

Myalgia, fatigue (thyroiditis, myasthenia, myositis)?

Fatigable proximal limb muscle weakness, shortness of breath, ocular complaints, dysphagia (myasthenic syndrome)?

Figure 3

Checklist for important questions to ask to potentially detect neurological irAEs 